\title{
Mycoflora of Maize in Niger State, Nigeria
}

\section{Hadiza Kudu Muhammad ${ }^{1}$, Daniel Ojochenemi Apeh ${ }^{1,2}$, Hadiza Lami Muhammad ${ }^{1}$, Yemisi Bose Olorunmowaju ${ }^{1}$, Ebere Ifeji ${ }^{1}$, Hussaini Anthony Makun ${ }^{1}$}

\author{
${ }^{1}$ Department of Biochemistry, Federal University of Technology, Minna, Niger State, Nigeria \\ ${ }^{2}$ Department of Biochemistry, Kogi State University Anyigba, Nigeria
}

\begin{abstract}
Fungi have been associated with contamination and spoilage of food. These organisms are known to thrive in different weather and environmental conditions. Maize kernel obtained from field, store and market from 25 Local Government Areas of Niger State within the month of August to September were analyzed for fungi occurrence using standard methods. Ten different fungus; Aspergillus niger, A. ochraceus, A. flavus, A. fumigatus, A. parasiticus, Mucor spp, Fusarium spp, Penicillium spp, Yeast and Rhizopus spp, were identified and isolated from the maize kernel. From the agro-ecological zones of the state, the most predominant fungi were Aspergillus species (241/345), Rhizopus spp (41/345) and Mucor spp (37/345) while Penicilium spp and yeast were the least identified. Within the zones, Aspergillus species have the highest occurrence; wet (65/95), driest (63/95), wettest (56/95) and dry zone (54/95) zones. The highest occurrence of fungi was found in the market sample (129) followed by store (112) and field (104). High percentage occurrence of $11.6 \%$ was recorded in Suleja, Wushishi, and Borgu Local Government Area, followed by 10.6, 10.1, 8.7, 9.7, 9.2, 8.7 and 8.2\% in Bosso, Tafa, Madalla, Minna, Paiko, Bida and Sabon wuse respectively. Mold species known to be mycotoxin producers were reported in this work. This poses as a risk factor to food safety.
\end{abstract}

Key words: Fungi, Maize kernel, Niger State.

\section{Introduction}

Fungi such as those belonging to the Aspergillus, Fusarium and Penicillium genera are food safety compromisers due to their ability to produce secondary metabolites known as mycotoxins [1], these toxins contaminate agricultural commodities and when ingested by animals or humans may pose detrimental diseases [2]. It is estimated that annual economic losses in Asia and Africa as a result of grain mould are in excess of US $\$ 130$ million [3]. Mycotoxins are generally associated with cancer, reduced growth, infertility, liver and kidney dysfunction, and death. These effects result from short term or long term exposure. Short time exposure to high level of aflatoxin in

\section{* Corresponding author: Apeh Daniel Ojochenemi, danapeh@gmail.com}

(cc) BY-NC-ND $\odot 2019$ A.D. Ojochenemi et al., published by De Gruyter Open. This work was licensed under the Creative Commons Attribution-NonCommercialNoDerivs 3.0 License
Kenya led to 125 deaths in 2004, while consumption of aflatoxin contaminated maize killed 106 natives of Western India in 1974 [4]. It is estimated by FAO that $25 \%$ crops grown all over the globe are contaminated by fungi toxins every year, annual losses from this is about 1 billion tons of foods and products. Fungi infestation of food and subsequent production of mycotoxin can occur at different points in the food value chain, such as during cultivation in the field, during processing, during transportation or storage $[5,6]$. Mycotoxin contamination of cereals or forages on field usually result from infection with a mycotoxigenic fungi or a symbiotic endophyte [7]. During processing, storage and transportation of harvested products, environmental conditions that favour fungi are the cause of contamination [8]. Maize (Zea mays L.) is one of the commonly cultivated food worldwide, which is a major staple in developing countries, mostly in the SubSaharan Africa. Maize being a common staple in 
West Africa [9], has been a very important starchy food for both human and animal consumption particularly in northern Nigeria. Maize is used to produce 'koko' or 'ogi' a traditional fermented paste, it is also used to make 'tuwo' a stiff porridge this food is very common amongst the northerners and middle belts, maize is also eaten when roasted or boiled as a snack during its harvest season [10]. It is reported that, United States of America is the largest producer of maize in the world, while China and Brazil follow [3]. In Africa, Nigeria is the second largest producer of maize following South Africa, Nigeria produced $10,790,600$ Mt of maize in 2014 [3]. Maize, which possesses large ears with many seeds / kernels, has been reported to be more susceptible to fungi and mycotoxin contamination than other cereals in Nigeria and in the United States [11,12]. Adesuyi [13] reported that of the grains produced in Nigeria in $1970-1971$, between 2.5 and $4.0 \%$ were lost to insects annually while between 1.25 and $3 \%$ were damaged by fungi. Okereke and Nwosu [14] reported an estimated loss of $58 \%$ of 1000 tonnes of maize due to insect and fungal attack.

From the time when the research on mycotoxins began in Nigeria in 1963, a lot of work have estimated mycotoxin levels in maize from different part of the country $[11,15,9,16,17,18,19,20]$. However little work has been done to ascertain the mycoflora in maize from Niger state, though Atehnkeng et al. [21] estimated the level of aflatoxin from three geo- agricultural zones of the state and Makun et al. [22] reported the occurrence of mycoflora contaminating maize from the state capital Minna. Since maize is one of the most cultivated food in Niger state which is used for several food and animal feed preparations, both locally and all over the country, it is therefore of paramount importance to know the occurrence of mycoflora in maize from the state. This work would therefore be relevant to food safety.

\section{Material and Methods}

\subsection{Sample location and sample collection} Samples of maize (95) were collected during the rainy season (August-September), from different local government areas of Niger State according to the four microclimatic zones of the state (Table 1). Niger State is the largest Nigerian state by area $\left(76,363 \mathrm{~km}^{2}\right)$; it lies between $10^{\circ} 00^{\prime} \mathrm{N} 6^{\circ} 00^{\prime} \mathrm{E}$ of the coordinate. It is hot and humid for most part of the year especially between May and October $\left(29.5^{\circ} \mathrm{C}\right.$ and $\left.73.1 \%\right)$ which is conducive for fungal growth. The state grows a large amount of maize amongst major crops like rice, sorghum, cowpea, millet, groundnut, yam and cassava, which are also grown in commercial quantity [23].

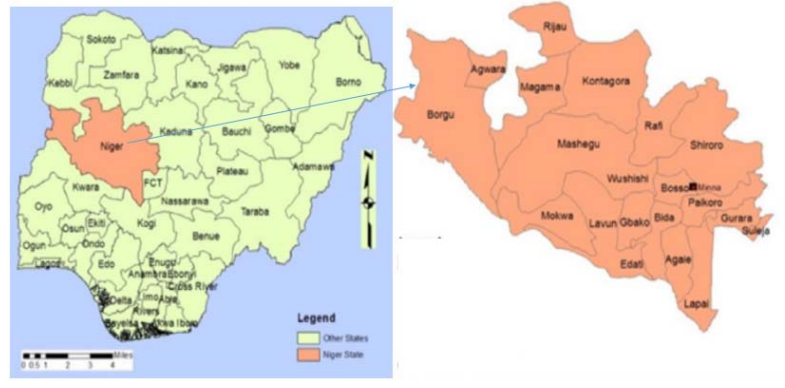

In each of the zones, samples were collected from field, store and market. Field samples were collected during the harvest period while those from the store were collected from locally built mud barns called "Rumbu" in Hausa language, the market samples were bought from different markets within the study area. About $300 \mathrm{~g}$ of each sample was collected, labeled and packaged in small containers and transported to the laboratory.

Niger State Local Government Areas (LGAs) according to microclimatic zones

Table 1.

\begin{tabular}{|c|c|c|c|c|}
\hline S/No & Zones & $\begin{array}{l}\text { Annual } \\
(\mathrm{mm})\end{array}$ & Range & Local Government Area \\
\hline I. & Wettest & $>1400$ & & Suleja and Tafa \\
\hline II. & Wet & $1200-1400$ & & Borgu and Magama \\
\hline III. & Dry & $1000-1200$ & & $\begin{array}{l}\text { Agaie, Agwara, Bida, Bosso, Edati, Gbako, Gurara, } \\
\text { Katcha, Kontagora, Lapai, Lavun, Mashegu, Minna, } \\
\text { Mokwa, Munya, Paiko, Rijau, and Shiroro }\end{array}$ \\
\hline IV. & Driest & $<1000$ & & Mariga, Rafi and Wushishi \\
\hline
\end{tabular}

\subsection{Preparation of sample for analysis}

Two grams $(2 \mathrm{~g})$ each of the samples were blended into fine flour using a milling machine (Greiffenberger Antriebstenchnic, Marktredwitz,
Germany). The flour was preserved in a clean dry container prior to usage. 


\subsection{Fungi Isolation and Identification}

The method described by Cotty [37] was used. The method used a Modified Rose Bengal Media (Sigma-Aldrich Chemie $\mathrm{GmbH}$ ) commonly called Clean up media (CU) for fungi isolation. The blended sample $(1 \mathrm{~g})$ was weighed into $10 \mathrm{~mL}$ of sterile-distilled water and mixed on a vortex mixer. The mixture was spread plated in three dilutions $(50 \mu \mathrm{l}, 100 \mu \mathrm{l}$ and $200 \mu \mathrm{l})$ on a CU media. This is to enhance the collection of isolates of fewer than 15 colonies from plates. The plates were incubated for 72 hours at $31^{\circ} \mathrm{C}$. After 72 hours, resulting fungi colonies were counted with a colony counter (Scienceware ${ }^{\circledR}$ colony counter system) under a magnifying lens. Aspergillus colonies that counted between 1-15 were transferred into a $5 / 2$ media (containing $50 \mathrm{~mL} / \mathrm{L}$ $5 \% \mathrm{~V}-8$ juice, $2 \%$ Bacto agar (Difco) set at $\mathrm{pH} 5.0$ 5.2 ), all other fungi were transferred into a full strength PDA Media (Sigma-Aldrich Chemie $\mathrm{GmbH}$ ) containing lactic acid (Sigma-Aldrich Chemie $\mathrm{GmbH}$ ) and further incubated for clearer growth.

Fungi identification: Isolates were classified on the basis of conidial morphology and colony characteristics. Microscopic examination coupled with atlas guide was used to determine other fungi genera and species. References used include; $[38,39,40]$.

Quantities of fungi were calculated as colonyforming units (CFU) per gram.

$c f u / g=\frac{\text { Number of colonies X Reciprocal of the dilution factor }}{\text { Plating volume }(1 \mathrm{ml})}$

\section{Results and Discussions}

Ten distinct fungus Aspergillus niger, $A$. ochraceus, A. flavus, A. fumigatus, A. parasiticus, Mucor spp, Fusarium spp, Penicillium spp, Yeast and Rhizopus spp, were isolated from maize kernel samples collected from market, field and store during this survey in Niger State. Across the agro-ecological zones Aspergillus species were the most predominant fungi identified, followed by Rhizopus spp and Mucor spp while Penicillium spp and yeast were the least identified (Table 2). This is in tandem with various reports from within and outside Nigeria, which shows similar fungi, isolates $[24,25,21,22]$. Aspergillus spp being the dominant amongst other species isolated is in agreement with Adebajo et al. [9], and Bankole and Mabekoje [19]. Aspergillus spp. were recovered from 61/91 maize samples from Ghana and Nigeria [26]. According to the report of Gonza' slez, et al. [25] the fungi that had higher occurrence in Northwestern Provinces of Argentina were Aspergillus niger, A. flavus, A. parasiticus, Mucor spp, and Rhizopus spp in maize. In maize kernels from Spain, Alborch et al. [27] reported occurrences of Aspergillus spp. (93.3\%), Penicillium spp. (83.3\%), Mucorales (53.3\%), Cladosporium spp. (43.3\%), Fusarium spp. (33.3\%) and yeasts (23.3\%). According to the authors, the remaining species (Beauveria spp., Trichoderma spp., Alternaria spp., Geotrichum spp., Paecilomyces spp., Scopulariopsis spp. and Acremonium spp.) were found in less than $20 \%$ of the samples. These reports from various continents clearly shows the ubiquity of fungi species. And explains why mycotoxin is a global challenge.

Among the most occurring fungi in our work and that of others reported, A. flavus is a popular name when it comes to production of the carcinogenous aflatoxin in maize worldwide $[28,29]$, this fungi is further classified as $L$ strain and $S$ strain based on genetic, morphological and physiological features. Those with fewer but larger sclerotia are the L-strain types while those with numerous small sclerotia are the S-strains. The Sstrains are more dedicated in production of aflatoxins than L-strains. A. flavus do not produce aflatoxin $G$ series due to a $1.5-2.2 \mathrm{~kb}$ deletion in the aflatoxin biosynthetic gene cluster, resulting in the loss of cypA gene. This gene is required for the production of $G$ series aflatoxins. Since the gene is present in the $A$. parasiticus they are able to produce $G$ series aflatoxins [28].

Another very important fungi mycotoxigenic fungi isolated in maize kernel is the Fusarium species which was just $2 \%$ of the total isolates. They are important for their role in causing a wide range of diseases to crops [30] and capable of producing several mycotoxins, including trichothecenes, zearalenone (ZEA), fumonisins, which are among the economically significant mycotoxins found in maize, rice and wheat (FAO, 2013). Xing et al. [31] isolated $F$. verticillioides $(24.77 \%), F$. graminearum (15.08\%), Fusarium spp. (5.54\%), A. flavus $(4.93 \%)$, A. niger $(7.51 \%)$, Penicillium spp. (3.86\%), Eupenicilliium sp. (1.82\%), Alternaria sp. (3.57\%), Trichoderma sp. (2.20\%) from maize kernel, establishing that Fusarium, Aspergillus, Alternaria and Penicillium occurred in pre-nature drying maize kernels as earlier claimed by Streit et al. [32]. In Qatar, F. verticillioides showed highest frequency distribution (34\%), followed by $F$. graminearum (16\%), F. oxysporum (15\%), F. proliferatum (13\%), F. culmorum $(8 \%)$, $F$. solani $(7 \%), F$. subglutinans $(4 \%)$ and $F$. avenaceum (3\%) in the feed cereals [33].

Based on geographical peculiarities, we categorized our sampling points into zones. The occurrence of Aspergillus species was highest in wet zone (65/95) and driest zone (63/95), and 
lowest in wettest zone (56/95) and dry zone (54/95) how ever in all cases occurrence was over $56 \%$. Out of the total 345 fungi identified, most fungi were identified from the wet zone (92) and driest zone (92), followed by the wettest zone (84) while the dry zone (77) has the least occurrence.
The occurrence of fungi in maize from different local government of Niger State is presented in table 3 , it shows that moulds occurred mostly in Suleja, Wushishi and Borgu LGAs, followed by Bosso, Tafa, Madalla, Minna, Paiko, Bida and Sabon wuse respectively.

\section{Occurrence of fungi in maize from Niger State}

Table 2.

\begin{tabular}{lcccccc}
\hline Fungi species & $\begin{array}{c}\text { Zone 1 } \\
\mathrm{n}=22\end{array}$ & $\begin{array}{c}\text { Zone 2 } \\
\mathrm{n}=25\end{array}$ & $\begin{array}{c}\text { Zone 3 } \\
\mathrm{n}=24\end{array}$ & $\begin{array}{c}\text { Zone 4 } \\
\mathrm{n}=24\end{array}$ & $\begin{array}{c}\text { Total Occurrence } \\
\mathrm{n}=95\end{array}$ & $\begin{array}{c}\text { Overall Occurrence } \\
\%\end{array}$ \\
\hline A. niger & 19 & 21 & 14 & 21 & 75 & 21.7 \\
A. ochraceus & 05 & 05 & 05 & 07 & 22 & 6.4 \\
A. flavus & 15 & 21 & 15 & 17 & 68 & 19.7 \\
A. fumigatus & 03 & 04 & 03 & 03 & 16 & 3.8 \\
A. parasiticus & 14 & 14 & 17 & 15 & 60 & 17.4 \\
Mucor spp & 08 & 06 & 14 & 09 & 37 & 10.7 \\
Fusarium spp & 03 & 02 & 03 & 01 & 09 & 2.6 \\
Penicillium spp & 02 & 02 & 01 & 03 & 08 & 3.5 \\
Yeast & 03 & 03 & 02 & 04 & 12 & 11.9 \\
Rhizopus spp & 12 & 14 & 03 & 12 & 41 & 100 \\
Total fungi count & 84 & 92 & 77 & 92 & 345 & \\
\hline
\end{tabular}

Fungi from cereals are commonly studied as field, store, and market source [21,10]. The fungi isolated from samples obtained from field, market and store in Niger State shows that Aspergillus niger, A. flavus, A. fumigatus, A. parasiticus and Rhizopus spp predominated more in samples from market while Mucor spp, Fusarium spp Rhizopus spp and Penicillium spp predominated more in the stored sample. Generally, Table 2 indicated that market sample (129) has the highest occurrence of fungi followed by stored samples (112) while samples from the field has the least (104). A studies has shown a high presence of both field fungi (e.g. Alternaria, Cladosporium, and Fusarium) and storage fungi (e.g. Aspergillus and Penicillium) in maize from Guatemala [34], such outcome may be related with elevated moisture during harvesting and throughout storage, as well as possible pestassociated wounds [35]. Water activity $\left(a_{w}\right)$ plays a significant role on the occurrence of fungi [31]. Widespread poor storage facilities and inadequate preservation methods, including inadequate drying may have also enhanced the growth of these

Table 3.

Occurrence of fungi in maize sample collected from different local government area of Niger state

\begin{tabular}{|c|c|c|c|c|c|c|c|c|c|c|c|}
\hline Fungi Species & $\begin{array}{l}\text { Tafa } \\
n=6\end{array}$ & $\begin{array}{l}\text { Madall } \\
\text { a } n=5\end{array}$ & $\begin{array}{l}\text { Suleja } \\
n=6\end{array}$ & $\begin{array}{l}\text { Sabon } \\
\text { Wuse } \\
n=5\end{array}$ & $\begin{array}{l}\text { Borgu } \\
n=6\end{array}$ & $\begin{array}{l}\text { Minna } \\
n=6\end{array}$ & $\begin{array}{l}\text { Bosso } \\
n=6\end{array}$ & $\begin{array}{l}\text { Bida } \\
n=6\end{array}$ & $\begin{array}{l}\text { Paiko } \\
n=6\end{array}$ & $\begin{array}{l}\text { Wushishi } \\
n=6\end{array}$ & $\begin{array}{l}\text { Frequency } \\
n=58\end{array}$ \\
\hline A. niger & 4 & 4 & 6 & 4 & 5 & 5 & 6 & 3 & 3 & 5 & 45 \\
\hline A. flavus & 4 & 1 & 6 & 3 & 5 & 5 & 6 & 3 & 4 & 4 & 41 \\
\hline A. ochraceus & 1 & 2 & 2 & 1 & 1 & 1 & 2 & 1 & 1 & 2 & 13 \\
\hline A. parasiticus & 4 & 5 & 3 & 2 & 4 & 4 & 5 & 5 & 3 & 4 & 39 \\
\hline A. fumigatus & & 1 & 1 & & 1 & & & & 1 & 1 & 05 \\
\hline Mucor spp & 3 & 2 & 2 & 3 & 1 & 3 & 1 & 6 & 3 & 2 & 26 \\
\hline Fusarium spp & 1 & 1 & & & 1 & & & & 2 & 1 & 06 \\
\hline Penicillium spp & 1 & & & & 1 & & 1 & & 1 & 1 & 05 \\
\hline Yeast & 1 & 1 & & 1 & 1 & & & & & 1 & 05 \\
\hline Rhizopus spp & 2 & 1 & 6 & 2 & 4 & 2 & 1 & & 1 & 3 & 22 \\
\hline Total & 21 & 18 & 24 & 17 & 24 & 20 & 22 & 18 & 19 & 24 & 207 \\
\hline occurrence & & & & & & & & & & & \\
\hline$\%$ Occurrence & 10.1 & 8.7 & 11.6 & 8.2 & 11.6 & 9.7 & 10.6 & 8.7 & 9.2 & 11.6 & 100 \\
\hline
\end{tabular}


Fungi are the major causes of spoilage in stored grains and ranked second only to insect infestation as a cause of deterioration and loss of food [10], the significant economic and health hazards caused by fungi and mycotoxin especially in developing countries cannot be over emphasized. The consequences of plant contamination by various fungi is not relegated to reduction in crop yield and quality with significant economic losses, but adulteration of grains with mycotoxins leads to serious diseases and even death [36]. Fungi are known to thrive in numerous conditions, but most importantly they grow in high temperate and moist environments, these conditions are more prevalent in wet zones, this may account for the high occurrence of fungi in wet zone (II). Other factors like insect infestation, agricultural practices, prolonged or bad storage system and microbial load could encourage fungal growth in grain in other conditions such as in a dry harsh environment as found in this study. Therefore, the continuous consumption of maize in Niger State without proper precautions may pose a threat to the health of human and animals alike.

\section{Acknowledgments}

The authors acknowledge the technical assistance of the laboratory staff of Microbiology and Biochemistry Department of the Federal University of Technology Minna and the contributions of Pius Ikokoh of Sheda Science and Technology Complex (SHESTCO), Abuja, Nigeria for the HPLC analysis.

\section{Conflict of Interest}

There is no conflict of interest on the work nor this report

\section{References}

1. CAST (Council for Agricultural Science and Technology) (2003). Mycotoxins - risks in plant, animal and human systems, Task Force Report, No. 139, Ames, lowa. pp1-191.

2. Bhat RV, Vasanthi S. (2003). Food safety in food security and food trade. Mycotoxin Food Safety Risk in Developing Countries IFPRI. Brief.

3. FAOSTAT: FAO Statistical Database, Food and Agricultural Organization of the United Nations, Rome, Italy, available at: http://faostat.fao.org/, last access: 18 December 2016.

4. Makun HA, Apeh DO, Rinde Y, Nagogo T, Okeke JO, Mustapha AS, et al.,. (2014). Determination of Aflatoxins in Sesame, Rice, Millet and Acha from Nigeria Using HPLC. Chemical Science Transactions; 3: 1516-1524.

5. Coulibaly O, Kerstin H, Bandyopadhyay R, Hounkponou S, Leslie JF, (2008). Economic impact of aflatoxin contamination in sub-Saharan Africa. In: Leslie, J.F., Bandyopadyay, R., Visconti, A. (Eds.),
Mycotoxins: Detection Methods, Management, Public Health and Agricultural Trade. CAB International, pp. 67-76.

6. Dawlal P, Barros E, Marais GJ, (2012). Evaluation of maize cultivars for their susceptibility towards mycotoxigenic fungi under storage conditions. Journal of stored products research, 48, 114-119. https://doi.org/10.1016/j.jspr.2011.10.006

7. Wilson DM, Abramson D, (1992). Mycotoxins. In: Sauer, D.B. (Ed.), Storage of Cereal Grains and their Products, fourth ed. American Association of Cereal Chemists, pp. 341-391 (chapter 10), 615.

8. Bailey JE. (1992). Whole grain storage. In: Sauer, D.B. (Ed.), Storage of Cereals Grains and their Products, fourth ed. American Association of Cereal Chemists, pp. 157-187 (chapter 5), 615.

9. Adebajo LO, Idowu AA, Adesanya OO. (1994). Mycoflora and mycotoxins production in Nigerian corn and corn-based snacks. Mycopathologia 126: 183-192. 10. Makun HA, Gbodi TA, Akanya OH, Salako AE, Ogbadu GH (2009). Health implications of toxigenic fungi found in two Nigerian staples: guinea corn and rice. African Journal of Food and Science 3: 250-256.

11. Opadokun JS, Ikeorah JN, Afolabi E, (1979). The aflatoxin contents of locally consumed foodstuffs, Part 3: Maize, Nigerian Stored Product Research Institute Report; NSPRI, llorin, Nigeria, pp. 105-108.

12. Lillehoj EB (1991). Aflatoxin: an ecologically elicited activation signal. In: Smith, J.E., Anderson, R.A. (Eds.), Mycotoxins and Animal Foods. CRC Press, Boca Raton, FL, pp. 119-139.

13. Adesuyi SA, (1972). The problems of storage of local foodstuffs in southern Nigeria. In: Annual Conference of the Nigerian Society of Plant Protection. 14. Okereke GU, Nwosu VC. (1987). Crop storage losses in southern Nigeria caused by the activities of microorganisms. MIRCEN. Journal of Microbiology and Biotechnology 3: 201-210.

15. Okoye ZS, (1993). Fusarium mycotoxins nivalenol and 4-acetyl-nivalenol (fusarenon-X) in mouldy maize harvested from farms in Jos district, Nigeria. Food Additives and Contaminants 10: 375-379.

16. Hell K, Udoh J, Setamou M, Cardwell, KF, Visconti A (1996). Fungal Infection and Mycotoxins in Maize in the Different Agro-ecological Zones of Benin and Nigeria. Food and Chemical Toxicology 4: 11-16.

17. Udoh JM, Cardwell KF, Ikotun T, (2000). Storage structures and aflatoxin content of maize in five agroecological zones of Nigeria. Journal of Stored Products Research 36: 187-201.

18. Bankole SA, Mabekoje OO, Enikuomehin OA. (2003). Fusarium spp. and fumonisin B1 in stored maize from Ogun State, Nigeria. Tropical Science 2003; 43: 76-79.

19. Bankole SA, Mabekoje OO. (2004). Occurrence of aflatoxins and fumonisin pre-harvest maize from southwestern Nigeria. Food Additives and Contaminants 21: 251-255.

20. Adejumo TO, Hettwer U, Karlovsky P. (2007). Occurrence of Fusarium species and trichothecenes in Nigerian maize International Journal of Food Microbiology, 116: 350-357

21. Atehnkeng J, Ojiambo PS, Donner M, Ikotun T, Sikora RA, Cotty, PJ. (2008). Distribution and 
toxigenicity of Aspergillus species isolated from maize kernels from three agro-ecological zones in Nigeria, International Journal of Food Microbiology; 122: 74-84. 22. Makun HA, Anjorin ST, Moronfoye B, Adejo FO, Afolabi,OA, Fagbayibo G, et al., (2010).Fungal and aflatoxin contamination of some human food commodities in Nigeria. African Journal of Food Science 4: 127-135.

23. Merem EC, Twumasi Y, Wesley J, Isokpehi P, Shenge M, Fageir S. \& Ochai S. (2017). Analyzing Rice Production Issues in the Niger State Area of Nigeria's Middle Belt. Food and Public Health, 7(1), 722. DOI: 10.5923/j.fph.20170701.02

24. Kpodo K, Thrane U, Hald B. (2000). Fusaria and fumonisins in maize from Ghana and their cooccurrence with aflatoxins. International Journal of Food Microbiology, 61:147-157.

25. Gonza' slez HHL, Resnik SL, Pacin, AM. (2003). Mycoflora of freshly harvested flint corn from Northwestern Provinces in Argentina. Mycopathologia; 155: 207-211.

26. Perrone G, Haidukowski M, Stea G, Epifani F, Bandyopadhyay R, Leslie JF, Logrieco A, (2014). Population structure and Aflatoxin production by Aspergillus Sect. Flavi from maize in Nigeria and Ghana. Food Microbiology, 41, 52-59. http://dx.doi.org/10.1016/j.fm.2013.12.005

27. Alborch, L, Bragulat, MR, Castellá, G, Abarca, ML, Cabañes, FJ (2012). Mycobiota and mycotoxin contamination of maize flours and popcorn kernels for human consumption commercialized in Spain. Food microbiology, 32(1), 97-103. doi:10.1016/j.fm.2012.04.014

28. Ehrlich KC, Cotty PJ, (2004). An isolate of $A$. flavus used to reduce aflatoxin contamination in cottonseed has a defective polyketide synthase gene. Appl. Microbiol. Biotechnol. 65, 473-478.

29. Donner M, Atehnkeng J, Sikora RA, Bandyopadhyay R, Cotty PJ, (2009). Distribution of Aspergillus section Flavi in soils of maize fields in three agroecological zones of Nigeria. Soil. Biol. Biochem. 41, 37-44.

30. Piacentini, K.C.; Rocha, L.O.; Savi, G.D.; Carnielli-Queiroz, L.; De Carvalho Fontes, L.;
Correa, B. (2019). Assessment of Toxigenic Fusarium Species and Their Mycotoxins in Brewing Barley Grains. Toxins, $11,31$. https://doi.org/10.3390/toxins11010031

31. Xing F, Liu X, Wang L, Selvaraj JN, Jin N, Wang Y. \& Liu Y. (2017). Distribution and variation of fungi and major mycotoxins in pre-and post-nature drying maize in North China Plain. Food control, 80, 244-251. http://dx.doi.org/10.1016/i.foodcont.2017.03.055

32. Streit E, Schatzmayr G, Tassis P, Tzika E, Marin D, Taranu I, et al. (2012). Current situation of mycotoxin contamination and co-occurrence in animal feed-focus on Europe. Toxins, 4(10), 788-809.

33. Hassan ZU, Al Thani R, Balmas V, Migheli Q, Jaoua $\mathbf{S}$ (2019). Prevalence of Fusarium fungi and their toxins in marketed feed. Food Control 104, 224-230. https://doi.org/10.1016/j.foodcont.2019.04.045

34. Hirst Sole LA, (1994). Algunos aspectos físicos y de procesamiento del maíz en grano y mazorca, con y sin tusa, almacenado en dos tipos de estructuras, con y sin tratamiento químico. Universidad del Valle de Guatemala. Ingeniería en Ciencias de Alimentos.

35. Mendoza JR, Kok CR, Stratton J, Bianchini A, Hallen-Adams HE, (2017). Understanding the mycobiota of maize from the highlands of Guatemala, and implications for maize quality and safety. Crop Protection, 101, 5-11. http://dx.doi.org/10.1016/j.cropro.2017.07.009

36. Marais GJ. (2000). Natural occurrence of mycotoxins in foods and feeds in South Africa. Submission to AFMA Technical Committee, Pp 88-92 37. Peter J, Cotty PJ (1994). Comparison of four media for the isolation of Aspergillus flavus group fungi. Mycopathologia 125: 157-162.

38. Klich MA (2002). Identification of common Aspergillus species. Utrecht: Central Bureau voor Schimmel cultures.

39. Ehrlich KC, Kobbeman K, Montalbano BG, Cotty PJ. (2007). Aflatoxin producing Aspergillus species from Thailand. Int J Food Microbiol. 114:153-159.

40. Pitt JI, Hocking AD. (2009). Fungi and food spoilage. London: Springer. 